УДК $811.161 .2 ’ 36$

Ж. В. Колоїз

\title{
ЛІНГВАЛЬНА ІНТЕРПРЕТАЦІЯ КОНЦЕПТУ ЛЮДСТВО В ПОЕТИЧНІЙ МОВОТВОРЧОСТІ ЛІНИ КОСТЕНКО
}

Колоїз Ж. В. Лінгвальна інтерпретація концепту ЛЮДСТВО в поетичній мовотворчості Ліни Костенко.

У статті йдеться про репрезентацію концепту людство в поетичній мовотворчості Ліни Костенко. Концепт людство схарактеризовано як особливу внутрішню організацію та складну структуру, сформовану на основі відповідного поняття, підгрунтям якого $\epsilon$ сукупність лексичних значень слова людство. Письменниця інтерпретує концепт людство крізь призму основних понять люди (люд), людина. Людину представлено не лише як біологічну, але й як соціальну істоту, що вирізняється як природженими, так і породженими в умовах суспільного життя властивостями, здібностями, манерою поведінки і т. ін. У більшості ситуацій сконцентровано найрізноманітніші образні асоціації.

Акцентовано, що семантика аналізованих лексем доволі часто конкретизується за допомогою епітетів внутрішньопсихологічного сприймання, а також так званих соціумних епітетів, які засвідчують соціальний статус, належність до тієї чи тієї формації, культури, території, виробничої сфери і т. ін. Це певною мірою свідчить про те, що людина як біологічна істота, яка належить до людської спільноти, не лише має психічні й фізичні відчуття, але й зазнає суспільно-історичного впливу. Зауважено, що художньо-семантична репрезентація концепту людство, грунтована на тріаді

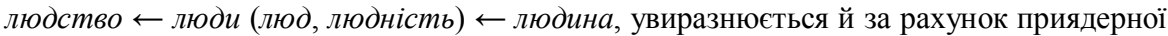
та периферійної частин.

Ключові слова: поетична мовотворчість, концепт, лексема, одиниця, значення, образні асоціації. семантичне наповнення.

Колоиз Ж. В. Лингвальная интерпретация концепта ЛЮДСТВО в поэтической речи Лины Костенко.

В статье идет речь о репрезентации концепта людство в поэтической речи Лины Костенко. Концепт людство характеризируется как особенная внутренняя организация и сложная структура, сформированная на основе соответствующего понятия, основой которого является совокупность лексических смыслов слова людство. Писательница интерпретирует концепт людство сквозь призму основных понятий люди (люд), людина. Человек интерпретируется не только как биологическое,

() ж. В. Колоїз, 2016. 
но и как социальное существо, которому свойственны как прирожденные, так и порожденные в условиях общественной жизни свойства, способности, манера поведения и т. д. В большинстве ситуаций сконцентрированы самые разнообразные образные ассоциации.

Акцентируется внимание на том, что семантика анализируемых единиц достаточно часто конкретизируется эпитетами внутрипсихологического восприятия, а также так называемыми социумными эпитетами, которые демонстрируют социальный статус, принадлежность к той или иной формации, культуре, территории, производственной сферы и т. д. Это в определенной степени свидетельствует о том, что человек как биологическое существо, принадлежащее к человеческому сообществу, не только имеет психические и физические ощущения, но и испытывает общественно-историческое влияние. Констатируется тот факт, что художественно-

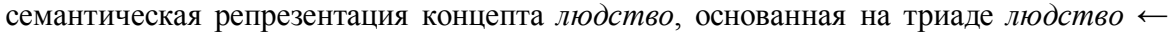
люди (люд, людність) $\leftarrow$ людина, делается выразительнее и за счет приядерной и периферийной частей.

Ключевые слова: поэтическая речь, концепт, лексема, единица, значение, образные ассоциации, семантическое наполнение.

Koloiz Zh. V. Lingual interpretation of the HUMANITY concept within the poetic works of Lina Kostenko.

The article represents the humanity concept in the poetic works of Lina Kostenko. The term "humanity concept" is determined as a special internal organization and complex structure which is formed by a set of the corresponding notions and lexical meanings of the word "humanity". Among these definitions can be distinguished the following: a) all people of the Earth, mankind, human society; b) people who live now and become the contemporaries to a certain person or some significant event; c) a large number of people united by certain positive traits.

The paper points at the fact that in terms of a certain context the analyzed language unit modifies its semantics in different ways. Humanity is perceived not only as a set of people consisting of individuals, but also it is supposed to be as a certain human community which has played a leading role in the cultural and historical processes. This article reveals the idea that within the poetic works of L. Kostenko the humanity concept is represented mainly through the prism of the people notion which is marked with multiple forms of expression and comes into synonymic relations with a colloquial word people. Lingual interpretation of the humanity concept is investigated through the prism of the person concept expressed by the word person.

Lina Kostenko successfully attempts to introduce a person not only as a biological individual, but also as a social creature. A person has both innate features and socially generated qualities, abilities, inclinations and behavior traits etc.

The thorough analysis demonstrates that fiction and semantic content of the humanity concept is built by the writer in a way of the triad: humanity $\leftarrow$ people (humanity) $\leftarrow$ person. This article confirms the idea that the semantics of the analyzed lexical units is often specified by using emotive innerperceived psychological adjectives and so-called social epithets certifying social status, belonging to this or that formation, culture, territory, production sphere. A person can adjust his / her natural temperament, control instincts and needs, perceive and 
understand aesthetic values, maintain mutual relations, communicate etc.

This paper also focuses on the analysis of verbs that accompany the word, used to denote the corresponding concept, including dynamic and state verbs of different kinds.

Key words: poetic works, concept, word, value, figurative associations, semantic content.

В українському мовно-літературному просторі Ліна Костенко як представниця нової генерації української інтелігенції, що увійшла в культуру в період тимчасового послаблення комуністичнобільшовицького тоталітаризму та хрущовської «відлиги», як митець, який вирізняється «культурологічною насиченістю поетичних медитацій» [2, с. 123], посідає важливе місце. Особливість ії творчості полягає в тому, «що вона завжди актуальна, а з часом набуває ваги» [6], бо репрезентує «олюднення часу, людського ментального упокорення минущості й утривалення творчого духу» [5]. Ї̈ї письменницький доробок, покликаний урятувати українську культуру від «духовної провінційності» [2, с. 130], неодноразово викликав зацікавлення науковців різних царин [10], однак «справжнє розуміння місця поезії Ліни Василівни в сучасній літературі (і мові - Ж. К.) та й у ширшому часовому континуумі ще тільки починається» [6], «ії поезія не вкладається у виміри сьогодення», а сама поетеса «уся іще в дорозі - до невідомого обрію свого людського й художнього єства» [1].

Художня довершеність, майстерність, потужний стилістичний потенціал, прагматична значущість, концептуальність і т. ін. поетичних текстів демонструють якісно новий рівень культурно-філософської думки й розвій української літературної мови, зразки нового, оригінального, «інтелектуального поетичного слова» [7, с. 187]. Лінгвістичні підходи, скеровані передусім на виявлення специфічних ознак ідіостилю письменниці, актуалізувалися у працях Т. Бабич, С. Барабаш, 3. Валюх, 3. Висоцької, В. Власенко, О. Дубовик, С. Срмоленко, І. Заремської, Т. Іванової, О. Ковалевського, О. Козлової, Ж. Колоїз, Т. Коляди, Н. Піддубної, Л. Ставицьої, І. Шапошникової та ін.

Творчість Ліни Костенко настільки популярна, що, здавалося б, важко відшукати той чи той аспект, який не привертав би увагу лінгвістів, проте письменницький доробок як джерельна база наукових студій з огляду на різновекторність дослідницьких підходів та наукових інтерпретацій дає невичерпні можливості щодо вибору предмета дослідження. До того ж розмаїтий ілюстративний матеріал, ๑ ж. В. Колоїз, 2016. 
уведений у науковий обіг, подекуди не підданий грунтовному й вичерпному аналізові. Це стосується передусім i явища, кваліфікованого в лінгвістиці як концепт, що являє собою вербалізоване вираження певного культурного змісту 3 усім розмаїттям супровідних значень та асоціацій, засвідчує національнокультурний та особистий досвід і знання людини про світ, а також $\epsilon$ прототипом групи похідних і взаємопов'язаних понять.

Питання концептуальних картин світу, концептосфер, концептів і т. ін. не є новими, однак не втрачають своєї перспективності, викликають неабиякий інтерес серед учених (А. Вежбицька, В. Гак, В. Звегінцев, О. Кубрякова, Л. Лисиченко, 3. Попова, О. Селіванова, Ю. Степанов, Й. Стернін, О. Тараненко, Г. Токарев, В. Ужченко та ін.).

Мета запропонованої статті - з'ясувати особливості репрезентації та лінгвально-художньої інтерпретації концепту людство в поетичній мовотворчості Ліни Костенко.

Концепт людство характеризується особливою внутрішньою організацією та складною структурою, формується на основі відповідного поняття, підгрунтя якого складає сукупність лексичних значень слова людство, зокрема: а) усі люди землі, рід людський, людське суспільство; б) люди, які зараз живуть на землі або $є$ сучасниками певної особи чи якоїсь знаменної події; в) велика кількість людей, об'єднаних певними позитивними ознаками [3, с. 499]. Наприклад: Який був світ / античний $i$ готичний! / Це снилось людству / чи таки було? / Світ робиться сухий $i$ прагматичний / Вже ледве б'є кастальське джерело (9, с. 264-265); Струїли все / пора на карантин / $i$ вам поля / й тобі соснова кроно / $A$ може й зараз твориться буритин / але про це ще людству невідомо (9, с. 265); Дай хоч на мить забути слово - «мушу», / це перше слово $з$ букваря дорослих. / Мені без тебе сумно серед людства. / Вже людству не до себе й не до нас. / А дика груша світиться, як люстра. / I чутно гомін тополиних трас... (9, с. 300); Мужчини, руки од мазуту вимивши, / ковтали в пресі де яка стаття, / оскільки людство допливло наввимашки / до значно вищих форм свого буття (9, с. 351); Чи ми кого в житі неправедно карали? / Чи, може, наш народ кого зі світу зжив? / От тільки і всього: у людства курку вкрали. / Чи, може, який цицган в полічії служив? (9, с. 404); Кити хоч викидаються на сушу. / А людству викидатися куди?! (9, с. 541); Чи страх 
пропориійний до маси тіла?/ На изьому дереві і людство - горобецьь. / Але ми знасм виміри легенди (9, с. 547) тощо.

У такому разі варто, очевидно, говорити про те, що в умовах того чи того контекстуального оточення аналізована лексема модифікує, конкретизує свою семантику: людство сприймається не лише як сукупність людей, що складається з окремих індивідів, а як та чи та людська спільнота, яка відіграла провідну роль у культурноісторичних процесах, посіла важливе місце в цивілізаційному просторі, досягла відповідного рівня суспільного розвитку i матеріальної культури: Те, щзо вчора було прогресом, / завтра стане іхтіозавром. / Але чи так уже й по висхідній / іде фантазія людства? (9, с. 545); Мабуть, ще людство дуже молоде. / Бо скільки б ми не загинали пальиі, - / ХХ вік! - ай досі де-не-де / трапляються іще неандертальичі $(9$, с. 64) (пор.: з одного боку, людство молоде, тобто людське суспільство, яке недавно виникло, має небагато років, не досягло зрілого віку [3, с. 537]; з іншого, - неандерталещь - «давня людина, що жила в епоху нижнього і середнього палеоліту в деяких районах земної кулі (безпосередній предок сучасної людини» [3, с. 591]). Попри те, що людство дуже молоде, воно цілком самодостатнє, окреслило свої духовні цінності, пріоритети, які сповідує, утвердило моральні закони, сформовані протягом не одного століття.

Звідси, відповідно, цілком закономірно, що письменниця доволі часто будує однорідні сурядні ряди, компоненти яких увиразнюють відповідну лінгвоодиницю, як-от: Душа належить людству $i$ епохам. / Чому ж ї̈ так раптом потрясли / осінні яблука, щуо сумно пахнуть льохом, / і руки матері, щзо яблука внесли? (9, с. 27); Ти схуд, Джордано. Одіспався б трохи. / Ти ж був дитя, вони вважали - тигр. / Ти все віддав для людства, для епохи. / Чи ти хоч, хлопче, налюбитись встиг? (9, с. 256), де епоха - «великий період часу 3 визначними подіями, явищами або процесами у природі, суспільстві, науці, мистецтві і т. ін.» [3, с. 266]; Хоч знаю: все це їй не первина. / Але колись нап 'ється ж до переситу! / Захоче винити не крові, а вина / за щзастя людства, / за здоров'я всесвіту! (9, с. 151), де всесвіт має переосмислену семантику, уживається у значенні «населення всієї землі» [3, с. 162]. У такому разі лексеми людство та всесвіт сприймаються як контекстуальні синоніми.

() ж. В. Колоїз, 2016.

$-194-$ 
Осмислення поняття людство відбувається 3 позицій духовно багатої і зрілої особистості, вихованої в дусі найкращих українських традицій, яка вболіває за долю роду людського, за всіх людей землі: Віки минули / $i$ віки грядуть / Чи людством бути / люди щุе спроможні? / Демографічні вулики гудуть / а стільники розтоптані й порожні (9, с. 262). У проілюстрованому контексті засвідчена тавтологія, побудована на зіставленні двох лексем, значення яких співвідносяться як загальне і часткове: людство - люди. Таке зіставлення $\epsilon$ непоодиноким, подекуди контексти репрезентують відповідні ієрархічні відношення, як-от: І хто ми є? Усі усім мільйони. / А хтось комусь однісінький-один. / Тому ми люди. І життя навколо. / Тому є людство. Нація. Сім'я. / Нема на світі в тебе вже нікого. / Але у тебе є на світі я $(9$, с. 397) (пор.: з одного боку, $九 \rightarrow м и \rightarrow y c i \rightarrow$ люди $\rightarrow$ людство; з іншого, - людство (тобто люди) $\rightarrow$ нація $\rightarrow$ сім'я, де нація - «конкретно-історична форма спільності людей, об'єднаних єдиною мовою і територією, глибокими внутрішніми економічними зв'язками, певними рисами культури і характеру» [3, с. 588]; сім'я «група людей, народів, націй, згуртованих дружбою, спільною діяльністю, спільними інтересами; родина» [3, с. 1129]. Лексичні значення відповідних лексем засвідчують як інтегральні, так і диференційні семи. До того ж відношення між компонентами людство, нація, сім'я можна розглядати не лише як ієрархічні, читати ïх «зліва» «направо», але й навпаки «справа» «наліво», зокрема: людство (тобто людське суспільство) $\longleftarrow$ начія $\longleftarrow$ сім'я, де суспільство - «сукупність людей, об'єднаних певними відносинами, зумовленими історично змінним способом виробництва матеріальних і духовних благ» [3, с. 1218]; нація - «конкретно-історична форма спільності людей, об'єднаних єдиною мовою і територією, глибокими внутрішніми економічними зв'язками, певними рисами культури і характеру» [3, с. 588]; сім'я - «група людей, що складається 3 чоловіка, жінки, дітей, інших родичів, що живуть разом; родина» [3, с. 1129]. Цілком очевидно, що поняття людське суспільство є ширшим за поняття нація, яке, своєю чергою, передбачає поняття сім'я у значенні «родина»; на основі загальнолюдських цінностей створюються національні, що лягають в основу не лише національного, а й сімейного виховання.

Людство, або людське суспільство, як відомо, вважають 
найвищим ступенем розвитку природного середовища, де люди (певна, зазвичай велика кількість людей) в усій сукупності і зв'язках становлять його ядро. Імовірно, саме тому в мовотворчості Ліни Костенко концепт людство репрезентовано переважно крізь призму поняття люди, позначуваного множинною матеріальною формою вираження: Подивишся: i що воно таке? / Не допоможе й двоопукла лінза. / Здасться ж, люди, все у них людське, / але душа ще з дерева не злізла (9, с. 64); В епоху спорту і синтетики / людей велика ряснота. / Нехай тендітні пальці етики / торкнуть вам серце і вуста (9, с. 66); A темрява! Іду, не спотикаюсь. / А люди, люди! Десь вони та є. / I всетаки, до чого я торкаюсь, / воно ж таки хоч трохи відтає (9, с. 215); Життя серед людей - / це та ж кімната сміху / Між тисячі дзеркал жахаєшся - / невже?! / Хто так спотворив нас? / Хто має з того втіху - / приписувати нам зображення чуже?! (9, с. 260); Біля стоянка первісних людей, / котра охороняється законом,- / палеоліт, печерна цитадель - / була між нами річка Рубіконом (9, с. 351); Бо це ж тобі не дворики ольвійські, / жінки в сандалях і тварини свійські. / Тут вільний cmen, і люди в ньому сущі, / на ичілий степ стада свої пасущі (9, с. 423); Понад Дніпром жили все хлібороби, / щзо звав їх Геродот борнсфеніти. / Були людьми не східної подоби, / лишили голос у віках дзвеніти (9, с. 427); Та тільки хто б на чому не спинився, / яких припущень ми б не спорудили,- / коли циим горам Київ ще й не снився, / тут люди вже на мамонта ходили (9, с. 428). Такі контексти актуалізують передусім основне значення (пор.: люди - «суспільні істоти, що являють собою найвищий ступінь розвитку живих організмів, мають свідомість, володіють членороздільною мовою, виробляють і використовують знаряддя праці» [3, с. 499]). Лексема люди використовується перш за все для позначення істот у протиставленні іншим істотам. У поєднанні з означенням, як-от, наприклад (первісні люди, люди не східної подоби), може сприйматися як матеріальна форма вираження, яка використовується для маніфестації осіб, «що належать до певної суспільної групи, середовища», об'єднаних певними характерними або спільними ознаками [3, с. 499], або осіб, задіяних у тій чи тій царині виробництва.

Десь-не-десь аналізована лексема може мати при собі квантитативний компонент, який увиразнює відповідну кількісну семантику: Хтось ними плакав, мучився, болів, / із них почав і ними ж () ж. В. Колоїз, 2016. 
i завершив, / Людей мільярди, і мільярди слів, / а ти їх маєш вимовити вперше! (9, с. 138);

Крім того, у поетичному доробку письменниці натрапляємо й на мовленнєві ситуації, що маніфестують розмовну лексему люд, яка вступає в синонімічні відношення зі словом люди, засвідчують зразки чи то абсолютних, чи то семантичних різновидів синонімів, де останні відрізняється один від одного тими чи тими семантичними відтінками: Наука вглиб, і прачя титанічна. / Загадка, не розгадана здавен, - / и це була експансія етнічна, / чи це союз споріднених племен? / Це люд місцевий чи це люди східні,- / у цъьому вчені теж неоднозгідні (9, с. 428); Які б тут не були стовпотворіння, / хто б звідки не накочував сюди, / а люд був корінний тут, бо коріння / в такому трунті глибоко сидить (9, с. 428); Слова уже не вірили словам / $i$ мружились од правди, як од сония. / Не переможе істина без нас. / Ой, скільки люду збіглось на Парнас! (9, с. 534). Зауважимо, слово люд, супроводжуване атрибутивним поширювачем, маніфестує й значення «група людей, належних до якого-небудь середовища»; «населення певної країни; народ» [3, с. 499] (пор.: люд місцевий і люди східні; люд корінний). 3 подібною семантикою (зокрема, «населення») образно використовується й лексема людність: Насправді ж тут, на узбережжях Лети, / не кіммерійці населяли край, / а перша людність тут була - таргети, / отож і пращур їхній - Таргітай (9, с. 433), що містить ремарку діал. [3, с. 499].

Лінгвальна інтерпретація концепту людство відбувається й крізь призму поняття людина, маніфестованого лексемою людина, якою поетеса послуговується насамперед для позначення будь-якої особи, кожного індивіда: Страждаю, мучусь, $i$ живу, $i$ гину, / благословляю біль твоїх тенет. / Цю грудочку тепла - у Всесвіті людину! / I Всесвіт изей-акваріум планет (9, с. 33); Митиюю не треба нагород, / його судьба нагородила. / Коли в людини є народ, / тоді вона уже людина (9, с. 38); Я чую смутку пальці крижані. / Розрісся ивинтар. Груша постаріла. / Мабуть, людину десь на чужині / отак би жодна пташка не зустріла (9, с. 67); Вирлооке сонще / сідає на чорну скелю. / 3 неба, гір і свободи собі вбудувала дім я. / Небосхил для людини - / якраз відповідна стеля. / Піднімеш думку - $і$ не розіб'сш їй тім'я (9, с. 142); Мої кохані, милі вороги! / Я мушу вам освідчитись в симпатії. / Якби було вас менше навкруги, - / людина може 
вдаритись в апатію (9, с. 150); Спортивна форма - гарне відчуття, / Марудна справа - жити без баталій. / Людина від спокійного життя / жиріє серием і втрачав талію (9, с. 150) тощо. Ліна Костенко робить загалом успішну спробу представити людину не лише як біологічну, але й як соціальну істоту, що вирізняється як природженими, так і породженими в умовах суспільного життя властивостями, здібностями, нахилами, манерою поведінки i т. ін. У більшості ситуацій сконцентровано та узгоджено найрізноманітніші образні асоціації (пор.: людина $\rightarrow$ грудочка тепла у Всесвіті, тобто має тепло, властиве живому організмові).

Людина - «одиничне до люди» [3, с. 499] - сприймається як щось незначне за величиною, особливо в тому разі, коли в тій чи тій мовленнєвій ситуації наявні й одиниці протилежної семантики (вказують на велику кількість), як-от: людина - народ (пор.: «1. Населення держави, жителі країни. 2. Форма національної та етнічної єдності» [3, с. 578]). Пор. також: Сказати б, зброя, ие хіба єдине? / Так щьо б зробили стражники юрбі? / $A$ в юрмах тих малесенька людина / тягла хреста важкого на собі $(9$, с. 364); Тепер Жар-птиці не буває. / Жар-птицю будень убиває. / Людина знівельована юрбою. / Заснути. Все забуть. Прокинутись собою $(9$, c. 541), де людина (малесенька людина) протиставляється юрбі «велике безладне, неорганізоване скупчення людей; натовп» $[3$, с. 1420$]$.

Звідси, відповідно, можна говорити про те, що художньосемантичне наповнення концепту людство письменниця вибудовує

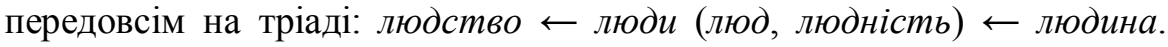
Аналізований концепт, крім ядра, містить у своїй структурі приядерні та периферійні елементи, представлені найрізноманітнішими мовними засобами, здебільшого лексемами.

Щоправда, іноді індивідуально-авторське потрактування відповідного поняття маніфестують i описові, перефрастичні конструкції: Дуиі людської туго і тайго! / Це гарний звір, без нього зле живеться. / Але не треба кликати його. / Він прийде сам і вже не відсахнеться (9, с. 82); У драмі людській небагато дій: / дитинство, юність, молодість і старість. / Роби щуо хоч, ридай або радій. / Неси свій хрест. Все інше - позосталість (9, с. 178); Посмішки, / цзвітіння людських облич - / червоні троянди пристрасті, / білий гнів ๑ ж. В. Колоїз, 2016. 
ломикаменю, / колюча шипшина зневаги, / сині іриси втоми,- / мене морозить, коди я бачу посмішку пошляка / або лакизи (9, с. 118); I знов те ж саме / знову за своє / I дух людський знемігся, / окрилатів / Христос / не знаю / може де $i \epsilon$ / Зате в очах рябіє од Пілатів (9, с. 266-267); Знав городища, i степи, i плавні. / Чув цілий хор людських різноголось. / Та вище, де Дніпро не судноплавний, / $i$ Геродоту буть не довелось (9, с. 428); Глухих лісів німі аборигени, / людського духу навіть не ази, / вже як не є-спасибі вам за гени. / Хай грають далі в довгої лози (9, с. 350). Еквівалентні слову аналітичні метафоричні висловлення є образними найменуваннями істот, осіб, описовими назвами за їхніми характерними ознаками, діями (пор., наприклад, душа - «внутрішній психічний світ людини з ії настроями, переживаннями та почуттями» [3, с. 252]; $\partial y x$ - «за релігійними уявленнями, безсмертна, нематеріальна основа в людині, що становить суть іiі життя, відрізняє від тварини; душа» [3, с. 252]). Подекуди метафора розширює логічні межі тієї чи тієї номінації (пор.: драма - «1. Літературний твір, побудований у формі діалогу без авторської мови і призначений для специфічного виконання. <..> 4. перен. Яка-небудь подія, що приносить горе, страждання і т. ін. в особистому або громадському житті. // Тяжке душевне переживання» [3, с. 246] і людська драма - «людське буття; життя, існування людини 3 усіма тяжкими душевними переживаннями»).

У розумінні Ліни Костенко людство є суб'єктним буттям суспільства, у якому відбувається становлення людей загалом і кожної людини зокрема: На старих фотографіях всі молоді. / За роками людина сама себе кличе. / У зіничях печалі, як в чорній воді, / відбиваються люди, дерева, обличчя (9, с. 392); Хороші діти. Спокійна совість. / Люблю свою працю. Щаслива в родині. / Чого ще треба сучасній людині? (9, с. 401); Усе було на світі позавчора. / В зіничях Часу предковічний лід. / Людино, людино, людино, людино! / Збери себе всю у собі воєдино (9, с. 535) тощо. У людському суспільстві формується світогляд, моральні принципи, громадянська позиція, мотиви поведінки і т. ін.: Тож веселімось, людоньки, на людях. / Хай меле млин свою одвічну дерть / Застряло серце, мов осколок, в грудях. / Нічого, все це вилікує смерть (9, с. 13); О, не взискуй гіркого меду слави! / Той мед недобрий, від кусючих бджіл. / Взискуй сказать поблідлими вустами / хоч кілька людям необхідних слів. / Взискуй 
прожить несуєтно і дзвінко. / Взискуй терпіння витримати все. / A справжня слава - це прекрасна жінка, / що на могилу квіти принесе (9, с. 52); I ні копійки ж, бо не візьме зроду, / бо щчо ви, люди, на чужій біді?! / А може, то в душі свого народу / я прихилила голову тодi? (9, с. 73); Смійтесь, люди. А діди зникають. / Сивий сон у вічність однесе... / С скарби, допоки їх шукають. / Перестануть - от тоді вже все (9, с. 109); Я гордий був. Принаймні хоч гордині / ніхто не сміс збавити людині (9, с. 487); У людини з фашизмом генетична несумісність. / Скажіть, будь ласка, фантасте Уеллс, / чи буває фантазія похмуріша, ніж дійсність? (9, с. 537); Такий туман, аж піють сірі півні. / Людина йде з туману у туман. / Ми всі, по суті, живемо / якоюсь мірою в тумані $(9$, с. 547); Хто дивиться нам вслід, / той плаче за собою. / Віддай людині крихітку себе. / За иче душа поповнюється світлом (9, с. 549).

Письменниця зазвичай не вдається до виокремлення людської унікальності чи неповторності: Повзе гадюка в чорний телефон. / Мигтять людей столикі дублікати. / А я стою. I ие мій марафон - / самій від себе безвісти тікати (9, с. 284); А ноги довгі, ноги, не котурни. / Б'ють по литках терни і бур'яни. / Стугнить земля. Ідуть великі юрми. / Ти думав - люди, глянув - барани! (9, с. 176). У першому контексті аналітична метафорична конструкція людей столикі дублікати є компресованою, згорненою одиницею тексту, достатньо інформативною, результатом індивідуально-авторського бачення відповідного предмета (пор.: столикий - «який виявляється в різноманітних формах; різноманітний» [3, с. 1199] і дублікат «другий примірник документа, що має однакову 3 оригіналом юридичну силу» [3, с. 250]; людей столикі дублікати «найрізноманітніші люди, безліч людей, що мають однакову подобу, повторюють, дублюють, наслідують чиї-небудь дії, поведінку, манери i т. ін., прагнуть бути цілком подібними до кого-небудь, схожими на когось», адже анатомофізіологічні характеристики генетично зумовлені, передаються по спадковості). У зв'язку з тим, що подібні метафори актуалізують не всі семи, залишається можливість різного сприймання і тлумачення. Це очевидно, адже семантична структура метафори завжди складна, вона асоціює щонайменше два об'єкти (пор.: ти думав - люди, глянув - барани, де лексема баран, що використовується для позначення нерозумної, слабодухої людини

() ж. В. Колоїз, 2016. 
[3, с. 36], засвідчує метафоричне перенесення за емоційним враженням від предмета (назва тварини $\rightarrow$ людина, подібна до цієї тварини за порівнюваними інтелектуальними здібностями, характером, особливостями поведінки).

У поетичному доробку Ліни Костенко семантика аналізованих лексем (людина $\rightarrow$ люди (люд, людність) $\rightarrow$ людство) доволі часто конкретизується за допомогою епітетів, передусім емотивних епітетів внутрішньопсихологічного сприймання: I чую тишу. I співають птиці. / Проходять люди гарні і незлі. / В пахучій хмарі дощуової глиці / стоїть туман, як небо на землі (9, с. 44); Лежи, Іване. Світ вже був немилий. / В дорозі вмерти - теж не до ладу. / Тут Рось тобі камінчиків намила, / з них добрі люди пам'ятник складуть (9, с. 240); А я дивлюсь і думаю про вірші. / Коли їм сумно - хай вони сумують. / Хай тільки не сміються штучним сміхом, / бо щирі люди зачиняють вікна (9, с. 136); Прощай, прощай, чужа мені людино! / Ще не було ріднішого, як ти. / Оие $і$ є той випадок єдиний, / коли найбільша мужність - утекти (9, с. 286); Про скіфів добре згадував Есхіл. / В Гомера є, що скіфи - справедливі. / В цььому краю царів $і$ пастухів / суворі люди, горді $i$ вродливі (9, с. 430); А навкруги - природа первозданна. / I люди щедрі й добрі, як вона. / Все їм дала богиня їхня Дана. / Живе народ. Кочують племена (9, с. 454); А не без того. Гетьмана - на покуті. / Такенна миска страви на столі. / I риба, й мед. Усе своє, напохваті, / У нас гостинні люди у селі (9, с. 518). Такі епітети здебільшого є постійними, у позитивному плані оцінюють відповідні суб'єкти буття (пор.: люди вродливі, гарні, гордi, добрі, щ̧едpi, щирі і т. ін. - люди, що мають привабливу зовнішність, привабливі риси обличчя, позитивні якості, сповнені особистої гідності, самоповаги, прямо, безкорисливо, чистосердечно виражають свої почуття, відверті, правдиві, доброзичливо, приязно, чуйно ставляться до інших людей, вирізняються зразковою поведінкою і т. ін.). Інакше кажучи, люди людяні: Не хочу я в рай, $i$ не заздрю я Крезові. / Заб'юся в глухий очей кут. / Тут сосни соснові, берези березові, / i люди людяні тут (9, с. 411) (пор.: людяний - «який щиро, доброзичливо, чуйно ставиться до інших; уважний до чужих потреб; гуманний» [3, с. 499]).

Схвальну характеристику репрезентують не лише так звані стверджувальні епітети, представлені матеріальною формою 
вираження, використовуваною для позначення тих чи тих високих моральних якостей, а й ті, які утверджують позитивну оцінку через заперечення, як-от люди гарні і незлі (пор.: незлий - «який не заподіює зла іншим, не схильний до цього; добрий; який виражає доброзичливість, прихильність до кого-небудь» [3, с. 603]).

Зауважимо, деякі 3 якісних непохідних прикметників $\epsilon$ постійними супровідниками лексеми люди, тривала традиція їх образного використання уможливила надання їм статусу готових образних засобів, якими можна послуговуватися як усталеними конструкціями, відтворювати їх у готовому вигляді: I сивий жрець сказав їм, як із неба: / - Гей, добрі люди, а чого вам треба? / Вклонились греки звичаям тутешніми / Спитали греки, щуо изе за ріка. / I сивий жрець вклонився низько теж їм, / хоча дивився дуже звисока $(9$, c. 458).

У контексті Відтак велично показав їм костуром - / там далі місто й люди не скупі. / Сказав, щзо обрій - цуе усмішка простору / $i$ щуо ім'я цій річечцуі - Супій $(9$, с. 458) конструкція люди не скупі являє собою епітетну предикативну основу, у якій загалом заперечується ознака, виражена предикатом у позиції присудка (пор.: скупий - «який уникає витрат; надміру, до жадібності ощадливий» [3, с. 1145] i щзедрий - «який охоче ділиться своїм майном, коштами і т. ін., не шкодує витрачати що-небудь» [3, с. 1413], тобто не скупий = щуедрий). Заперечна модальність наявна й тоді, коли авторка робить спробу окреслити віковий етап, період життя: Але ж, даруй, ми люди не cmapi. / Хіба можливо, шуоб така скульптура / стояла тут у нас в монастирі? (9, с. 509).

У творчості поетеси натрапляємо й на кількакомпонентні марковані атрибути (Пливуть вони між тими берегами. / А скрізь луги безмежні за лугами. / Пішуаний берег в решеті стрижів. / I добрі люди гарних типажів (9, с. 457), які мають образно-означальне наповнення (пор.: добрі люди гарних типажів).

Чимало атрибутивних поширювачів демонструють відповідний соціальний статус, належність до тієї чи тієї формації, культури, території, виробничої сфери і т. ін.: I десь, в якійсь пустелі, з ’̈дять його верблюди. / Забудуть його діти, і виростуть німі. / Бредуть, бредуть вигнаниі.../ бредуть бездомні люди.../ Ні даху ж, ні притулку, - буквар їм на умі! (9, с. 23); На берег, вийили, б люди тогобічні, / $і$ мовчки() Ж. В. Колоїз, 2016. 
мовчки,бачили б вони, / щุо иче пливе князь Полоцький, у вічність, / а з ним Рогніда і його сини (9, с. 379); Коли в лісах ревли іще буй-тури, - / Дажбогу сонце приміряло німб, / $і$ люди чорноліської культури / жили, співали, сіяли свій хліб (9, с. 428); Ніхто з купців тут не застряв ні разу. / Були тут греки і майстри з Кавказу. / I фінікійці, люди всюдисущі, / не раз перепливали тут по суші $(9$, с. 452); Ніхто із вас додому не доїде, / з'їять вас андрофаги-людоїди. / Тут люди дикі у своїй основі. / Будини тут їдять шишки соснові (9, с. 453); Тут люд осілий. Тут шанують труд. / I рух дадуть $і$ кругові, і кросну. / Кують залізо із місиевих руд. / I мають славу дуже розголосну (9, с. 442); Шумів базар. Проходили транзити. / Лежали хури червонястих руд. / Вгорі жили царі і ворожбити. / Внизу роївся ремісничий люд (9, с. 443); Там зброю вміють у руках тримати. / Живуть на схилах люди з ремеслом. / тут з кущів як вискочать сармати,- / чим будеш одбиватися, веслом? $(9$, с. 458$)$ тощо.

Це певною мірою свідчить про те, що людина як біологічна істота, яка належить до людської спільноти, не лише має психічні й фізичні відчуття, але й зазнає суспільно-історичного впливу. Вона може коригувати свій природний темперамент, приборкувати інстинкти, керувати потребами, здатна сприймати й усвідомлювати естетичні цінності, підтримувати взаємні стосунки, порозумітися, передавати досвід і т. ін.: Не встигнеш людям передати й досвіду. / Лии блискавки напишуть від руки, як ти загинув, Дон Кіхоте, вдосвіта, / шукаючи грукучі вітряки (9, с. 177); Людей на світі смуток не трима / Розвію хмару над життям навислу / Іронія - / це блискавка ума / котра освітить всі глибини смислу (9, с. 267); I верби прийтли. I прийшло незабутнє. / I люди, й не люди, добро $i$ зло. / Але майбутнє тому $i$ майбутнє, / щзо має бути, щзо б не було! (9, с. 110); Ой доле, доле, щзо з людьми ти коӥи? / Цим осокорам вже по двісті літ. / Із катапульти гойдалки такої ж / колись я звідси вилетіла в світ (9, с. 112); А хто ж розкаже людям про ті криваві сльози / у тих лісах волинських, де пам'ять аж / кричить,- / коли ми йшли в безвихідь, у голод, у морози, / тікаючи од звіра, щуо звався геноцид?! (9, с. 409); Живе у Римі. Має свій куток. / Згорбатів у труді, посивів у скорботі, / а людям чорно в роті од пліток $(9$, с. 497). Як справедливо зауважують учені різних наукових царин, «людина постає єдністю, сумою та органічним породженням і продовженням власної минувшини, а сутність людини значною мірою 
формує ii iсторія», «у структурі пріоритетів людини вагому роль відіграють соціумні орієнтації, що спричиняють не лише вчинкові, але й поведінкову культуру» [4, с. 218]. У такому разі узуальний сегмент поняття «людина» доповнюється індивідуально-авторським, що маніфестує додаткові смисли, які увиразнюють, конкретизують, доповнюють узагальнені знання соціуму, зокрема про людину як суспільну істоту, покликану зберігати духовну й інтелектуальну культуру етносу [8, с. 217].

Водночас людина є біологічним видом Homo sapiens, частиною природи і мала б гармонійно вписуватися в природне середовище, мирно співіснувати 3 іншими його елементами, зокрема рослинним $\mathrm{i}$ тваринним світом: Малі озерияя блискають незлісно, / колише хмара втомлені громи. / Поїдемо поговорити з лісом, / а вже тоді я можу $і$ з людьми (9, с. 51); Сосновий ліс перебирає струни. / Рокоче тиша на глухих басах. / Бринять берези. I блукають луни, / людьми забуті звечора в лісах (9, с. 108); Шипшина важко віддає плоди. / Вона людей хапає за рукава. / Вона кричить: Людино, підожди! / О, підожди, людино, будь ласкава. / Не всі, не всі, хоч ягідку облиш! / Одна пташина так мене просила! / Я ж тут для всіх, а не для тебе лиш. / I просто осінь щэоб була красива (9, с. 336). Однак, на превеликий жаль, життя вносить свої корективи, людські вчинки доволі часто суперечать суспільним законам, $є$ аморальними й такими, що викликають осуд і супротив, як-от: I тільки при людях, мабуть, / дерева тремтять від жаху, / бо кращих із них поведуть / ні за що ні про щзо на плаху $(9$, с. 124). У таких ситуаціях розгортається складна система стосунків людини і природи.

Лексеми, що використовується для позначення аналізованих понять, супроводжуються дієсловами буття, дії, психологічного / фізіологічного стану чи процесів, ментальних i соціальних дій суб'єкта (фізичної чи інтелектуальної діяльності або відпочинку, мовлення, мислення, пізнання, сприйняття) і т. ін.: $A$ вів їм склав усі свої трофеї - / кремінний ніж, сокиру кам'яну. / - Чи не прибив нас

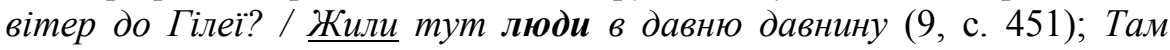
переходять илях уповні, / Під осінь в кожному селі / немов димки димлять жертовні - / копають люди картоплі (9, с. 123); I сміються люди вже у вічі: / треба ж так от збутися ума, / щзоб оце в двадиятому сторіччі / та шукати те, чого нема! (9, с. 109); Ви ๑ ж. В. Колоїз, 2016. 
ставите вище комір. / А всі ідуть звідусюди. / Чи иче Вам так тільки здасться? / Це осінь так шелестить, / Пробачте їм, пане Гамсун. Вас надто любили люди, / $A$ Ви їх так ошукали, вони не зможуть простить (9, с. 253-254); А люди спали. Людям снились жахи. / Хтось щзось палив. Їм снилася війна. / А дим казав: - Вона вже грала в шахи / сама з собою. Виграла слона (9, с. 246); Вже й пес не гарчить. I I осінь / захрипла шерехом криги. / I садівник оббиває об дерево чорні граблі. / А люди проходять, проходять, і просто кидають книги. / Так просто, як у могилу кидають грудки землі (9, с. 254); Чи зрікся Галілео Галілей? / Щось люди там балакали про втому. / Про те, щзо рятувався він. Але й / не певна я, бо не була при тому (9, с. 227); E, щзоб люди знали! / Он як про тебе і про Сулиму, / як ви Кодакфортецю зруйнували, / а потім як на страту вас везли, / $і$ як ти чудом жив-здоров лишився, / та й знов на Січ подався Низову,- / от про таке у нас в селі співали! / I люди плакали. Але ж то й сльози інші $(9$, с. 523) тощо.

Людина здатна контролювати свої дії і вчинки, несе за них відповідальність. Правильність, розумність чиєїсь поведінки великою мірою залежить від віри, як від «упевненості в чомусь, у здійсненні чого-небудь», так і від «визнання існування Бога, переконання в реальному існуванні чогось надприродного» [3, с. 147]. Авторка констатує: Я в людей попрошу тільки віри / в кожне слово, почуте від мене, / в кожний погляд очей моӥх сірих, / в кожну ласку рук нестудених (9, с. 139); I завжди люди гинули за віру. / Цей спорт одвічний винайтли не ми. / Тут головне - дивитись в очі звіру / $i$ просто - залишатися людьми (9, с. 205); Сдиний Боже! Все обсіли хами. / Веди мене шляхетними шляхами. / I не віддай циим людям на поталу,- / вони вже іншу віру напитали (9, с. 217). У подібних ситуаціях, цілком закономірно, актуалізується й лексема віра. Щоправда, подекуди про належність до того чи того віросповідання письменниця говорить метафорично, послуговуючись лексемами певної семантичної групи: Не визнають тут Зевса і Паллади. / Тут сповідають люди на Дніпрі / високий культ астральної тріади - / культ Місяия, культ Сония, культ Зорі (9, с. 454); Лиш храм збудуй, а люди в нього прийдуть. / Не бий на сполох в невідлитий дзвін $(9$, c. 545). Особа як утілення високих інтелектуальних і моральних властивостей, якою є людина, усупереч обставинам, повинна робити 
те, що узгоджується 3 загальнолюдськими цінностями. I передусім згадати про людське в людині.

Ліна Костенко, змальовуючи реалії сьогодення, закликає виходити зі стану спокою, застою i т. ін., ставати активними, діяльними: Усі усіх не люблять. Це біда. / Це чорний дим невидимого пекла. / Ми вчаділи за декілька століть. / В иій n'єсі диригує сам диявол. / Просніться, люди! Це погані сни (9, с. 549). Через подібні звертання письменниця привертає увагу до висловленого, акцентує на актуальності інформації, що стала сутністю відповідної комунікативної ситуації і задля повідомлення якої ця комунікація відбулася. Пор. також: Люди мої, рідна моя рідність! / Щось мені так сумно, аж лякаюсь. / Щось приходжу я в невідповідність, / $і$ чомусь, злочинниця, не каюсь (9, с. 172); І якби на те моя воля, / написала б я скрізь курсивами: / - Так багато на світі горя, / люди, будьте взаємно красивими! (9, с. 193); Мікро-Содом, зашторена Гоморра, / просніться, люди, чуєте, біда! / Гули вже сходи маршем Чорномора, / стелився дим, як сива борода (9, с. 246-247) тощо.

Художньо-семантична репрезентація концепту людство,

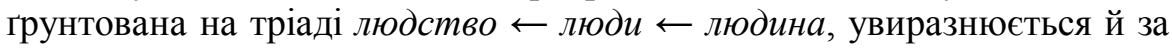
рахунок приядерної та периферійної частин, що пов'язуються, наприклад, з лексемами на позначення родинних стосунків на зразок чоловік, жінка і т. ін., 3 найменуваннями осіб за сферою діяльності і т. ін.: Він прихилився раптом до колони. / Сльоза чомусь набігла до повік. / Бо, знаєте... із каторги в салони... / не зразу усміхнеться чоловік... (9, с. 16); А потім зникла музика. Антракт. / Усі мужсчини говорили прозою. / Жінки мовчали. Все було не так. / ̈̈м не хотілось пива і морозива (9, с. 46); Старий співав без гриму і гримас. / Були слова палкими й не сучасними. / O, заспівайте дівчині романс! / Жінки втомились бути не прекрасними (9, с. 46). I не тільки. Їх грунтовне дослідження, лінгвальна інтерпретація у творчому доробку письменниці вимагає окремої уваги, дасть змогу змоделювати відповідну концептосферу індивідуально-авторського стилю, проілюструвати концептуальну парадигму.

Мовотворчість Ліни Костенко засвідчує посилений інтерес до суб'єкта буття, співвідносного передовсім із людським індивідом, у ширшому потрактуванні - iз сукупністю людських індивідів, людською спільнотою, родом людським. Матеріальною основою (ㄷ) Ж. В. Колоїз, 2016. 
(організуючим ядром) концепту людство, репрезентованого творчим доробком письменниці, є лексеми людина $\rightarrow$ люди (люд, людність) $\rightarrow$ людство. Зміст аналізованого концепту грунтується на контекстуальному оточенні, що уможливлює виявлення тих чи тих семантичних площин та образних характеристик.

\section{Література}

1. Банківська Н. «Я вибрала... долю, а не вірші». Ліні Костенко - 75 [Електронний pecypc] / Н. Банківська, А. Яковець // Дзеркало тижня. - 2005. - 19 березня. - № 10 (538). - Режим доступу : http://gazeta.dt.ua/SOCIETY/ya_vibrala_ dolyu,_a_ne_ virshi_lini_kostenko_75.html

2. Брюховецький В. С. Ліна Костенко. Нарис творчості / В. С. Брюховецький. К. : Дніпро, 1990. - 262 с.

3. Великий тлумачний словник сучасної української мови / упорядн. та гол. ред. : В. Т. Бусел. - К. - Ірпінь : Перун, 2009. - 1736 с.

4. Голобородько К. Лінгвоментальне моделювання когніотипу ЛЮДИНА в Олесевій мово сфері / К. Голобородько // Голобородько К. Ідіостиль Олександра Олеся : лінгвокогнітивна інтерпретація. - Харків : ХІФТ, 2010. - С. 218-296.

5. Дзюба I. «Мадонна перехресть» : Розділ 3 книжки «Є поети для епох» [Електронний ресурс] / I. Дзюба // День. - 2011. - №205. - Режим доступу : http://www.day.kiev.ua/uk/article/panorama-dnya/madonna-perehrest

6. Дроздовський Д. «Поезія Ліни Костенко в часах перехідних і вічних, або післямова до круглого столу» [Електронний ресурс] / Д. Дроздовський // Дзеркало тижня. - 2005 . - 16 липня. - № 27 (555). - Режим доступу : http://gazeta.dt.ua/CULTURE/poeziya_lini_kostenko_v_chasah_perehidnih_i_vichnih,_abo _pislyamova_do_kruglogo_stolu.html

7. Єрмоленко С. Я. Інтелектуалізація сучасної літературної мови в поезії Ліни Костенко / С. Я. Срмоленко // Мовно-естетичні знаки української культури : [монографія] / С. Я. Срмоленко. - К. : Балюк І. Б., 2009. - С. 187-200.

8. Колоїз Ж. В. Афоризми Ліни Костенко як транслятори загальнолюдських цінностей і національних пріоритетів / Ж. В. Колоїз // Філологічні студії : Науковий вісник Криворізького національного університету : зб. наук. праць. - Вип. 11. / [редкол. : Ж. В. Колоїз (відп. ред.), П. І. Білоусенко, А. З. Брацкі та ін.]. - Кривий Ріг, 2014. - С. 210-232.

9. Костенко Л. Вибране / Ліна Костенко. - К. : Дніпро, 1989. - 558 с.

10. Ліна Костенко : біобібліографічний покажчик / уклад. А. І. Мартинюк ; відп. за вип. Т. Є. Клименко ; за ред. Т. Є. Клименко. - Житомир, 2012. - 44 с.

Стаття надійшла до редакиї 19.11.2015 p. 